\title{
Optimizing ACtivity OF HeRbicides at REDUCEd RATE ON Emex spinosa CAMPD. WITH ADJUVANTS ${ }^{1}$
}

\author{
Otimizando Atividade de Herbicidas em Dose Reduzida na Emex spinosa Campd. com \\ Adjuvantes
}

JAVAID, M.M. ${ }^{2}$, TANVEER, A. ${ }^{3}$, AHMAD,.$^{4}{ }^{4}$ YASEEN, $M .{ }^{5}$ and KHALIQ, A. ${ }^{3}$

\begin{abstract}
In pot experiments, two adjuvants were evaluated for their efficacy in enhancing activity of five herbicides applied at reduced rates $(75 \%$ of the recommended rates) on Emex spinosa at the cotyledon-leaf and at the two- to four- leaf stage. Herbicides (at recommended rates) including fluroxypyr+MCPA at $450 \mathrm{~g}$ a.i. ha ${ }^{-1}$, carfentrazone-ethyl at $20 \mathrm{~g}$ a.i. ha ${ }^{-1}$, bromoxynil+MCPA at $450 \mathrm{~g}$ a.i. ha ${ }^{-1}$, thifensulfuron-methyl at $75 \mathrm{~g}$ a.i. ha ${ }^{-1}$ and tribenuronmethyl at $75 \mathrm{~g}$ a.i. ha $\mathrm{a}^{-1}$ alone and tank mixed at reduced rates with adjuvants, namely, alkyl ether sulphate sodium salt at $625 \mathrm{~mL} \mathrm{ha}^{-1}$ or fatty alcohol ethoxylate at $375 \mathrm{~mL}^{-1}$. Addition of the adjuvants to reduced rates of fluroxypyr+MCPA and carfentrazone-ethyl, increased their efficacy with $100 \%$ mortality and biomass reduction of $E$. spinosa at the cotyledon- leaf stage and at the two- to four- leaf stage which was similar to their recommended rates without the adjuvants except for carfentrazone-ethyl at a reduced rate without adjuvants at the two- to four- leaf stage. Bromoxynil+MCPA at reduced rates with alkyl ether sulphate sodium salt also gave $100 \%$ control of $E$. spinosa over weedy check at the two- to four- leaf stage. Both the adjuvants generally increased the efficacy of tribenuron-methyl at reduced rates when sprayed at both leaf stages. These findings suggest that the use of adjuvants may increase the efficacy of the above mentioned herbicides against $E$. spinosa and it may be incorporated in an integrated weed management program.
\end{abstract}

Keywords: alkyl ether sulphate sodium salt, devil's thorn, fatty alcohol ethoxylate, herbicides, weed leaf stages.

RESUMO - Em experimentos em vasos, dois adjuvantes foram avaliados quanto à sua eficácia em melhorar a atividade de cinco herbicidas aplicados em doses reduzidas (75\% da dose recomendadas) na folha de cotilédone de Emex spinosa, nos estádios de duas a quatro folhas. Os herbicidas (com as doses recomendadas) foram: fluoxipir+MCPA a $450 \mathrm{~g}$ a.i. ha ${ }^{-1}$, carfentrazone-ethyl a $20 \mathrm{~g}$ i.a. ha ${ }^{-1}$, bromoxinil + MCPA a $450 \mathrm{gi.a}$. ha ${ }^{-1}$, thifensulfuron-methyl a $75 \mathrm{gi}$.a. ha $\mathrm{a}^{-1}$ e tribenuron-methyl a $75 \mathrm{~g}$ a.i. ha $\mathrm{a}^{-1}$ sozinho e em tanque de mistura a doses reduzidas com adjuvantes, a saber: alquilo éter sulfato sal sódico em $625 \mathrm{~mL} \mathrm{ha-1}$ ou álcool etoxilato graxo em $375 \mathrm{~mL} \mathrm{ha}^{-1}$. A adição dos adjuvantes em reduzidas doses de fluroxipir + MCPA e carfentrazone-ethyl aumentou sua eficácia, com $100 \%$ de mortalidade e redução da biomassa de $\boldsymbol{E}$. spinosa no estádio de folha-cotilédones e no estádio de duas a quatro folhas, que foram semelhantes às doses recomendadas sem os adjuvantes, exceto carfentrazone-ethyl em dose reduzida sem adjuvantes no estádio de duas a quatro folhas. Bromoxinil + MCPA em doses reduzidas, com alquil éter sulfato sal sódico, também proporcionou 100\% de controle de $\boldsymbol{E}$. spinosa em verificação de infestação no estádio de duas a quatro folhas. Ambos os adjuvantes aumentam a eficácia do tribenuron-methyl em doses reduzidas quando pulverizados sobre as folhas, em ambos os estádios. Esses resultados sugerem que a utilização de adjuvantes pode aumentar a eficácia dos herbicidas mencionados contra $\boldsymbol{E}$. spinosa, os quais podem ser incorporados em um programa integrado de controle de plantas daninhas.

Palavras-chave: alquil éter sulfato sal sódico, espinho do diabo, álcool etoxilato graxo, herbicidas, estádios das folhas de plantas daninhas.

Recebido para publicação em 25.6.2011 e aprovado em 24.11.2011.

2 Department of Agronomy, University College of Agriculture, University of Sargodha, 40100, Pakistan. $<$ mmansoorjavaid@gmail.com>; ${ }^{3}$ Department of Agronomy, University of Agriculture Faisalabad, 38040, Pakistan; ${ }^{4}$ Department of Crop Physiology, University of Agriculture Faisalabad, 38040, Pakistan, ${ }^{5}$ Institute of Soil and Environmental Sciences, University of Agriculture Faisalabad, 38040, Pakistan. 


\section{INTRODUCTION}

Emex spinosa (Devil's thorn) is a serious weed of cereal crops and pastures (Kammoun $\&$ Souissi, 2009). It is an annual weed of the Polygonaceae family which is native to the Mediterranean region (Steinheil, 1838). Recently the presence of this weed has been reported as a potential future threat to the agro-ecosystems of the Southern Punjab in Pakistan. This weed is about 0.3-1.0 meter tall, decumbent or ascending with smooth ovate to nearly triangular 0.03 meter large leaves and woody fruits, tipped with three sharp and hard spins which cling to grazing animals and automobile tires and is, thereby, carried to new localities (Motooka et al., 2003). The continous establishment of $E$. spinosa in agricultural and range lands has been due to prolonged seed germination, emergence, rapid growth and prolific seed production potential of this weed. It is difficult to control due to its fleshy taproot that makes it possible to complete its life cycle by absorbing and storing moisture for its development (Hosaka \& Thistle, 1954) and re-sprouting ability. It germinates and grows during winter (November and December) and attains maturity in March or April before harvesting of wheat, barley, chickpea and lentil begins. In addition to its competitive effects on major crops, it is recognized as a problematic weed because of abundant spiny seeds which adversely affect harvest efficiency and crop quality.

The phytotoxicity of post-emergence herbicides can be increased with the addition of adjuvants to herbicide solutions (Adamczewski \& Matysiak, 2005; Bernards et al., 2009). Adjuvants are especially effective in improving the biological activity of herbicides by altering spray solution, surface tension, density, $\mathrm{pH}$, viscosity, drop size and distribution (Green \& Cahill, 2003). Herbicide rate reduction is a research priority to minimize environmental hazards and to increase the cost/benefit ratio (Woznica, 1995). Herbicides application rates can be reduced by up to $75 \%$, usually when applications are made during early growth stages (Zawierucha \& Penner, 2001b) or in combination with adjuvants (Lu et al., 2005; Zawierucha \& Penner 2001a). However, successful control using reduced herbicide rate depends on the herbicide being applied and specific characteristics of the target weed (Bunting et al., 2004). Identification of the appropriate adjuvants for a specific herbicide and weed specie is thus required to maximize herbicide performance (Wanamarta \& Panner, 1989). Adjuvants such as fatty alcohol ethoxylate and alkyl ether sulphate sodium salt are reported to increase the efficacy of foliar applied herbicides (Zabkiewicz, 2000; Hazen, 2000) and could be integrated potentially into a reduced herbicide rate program. Biological control of $E$. spinosa has been published by many researchers (Burdon \& Marshall 1981; Wilson 1964) but no work has been done on chemical control of E. spinosa. The objective of this study was to determine the potential of five herbicides at reduced rates with adjuvants in controlling $E$. spinosa at different growth stages.

\section{MATERIAL AND METHODS}

\section{Plant establishment}

Mature seeds of E. spinosa were collected from farmers' field of wheat. The seeds were cleaned and dried for 7 days at room temperature $\left(25^{\circ} \mathrm{C}\right)$ and then stored in a paper bag at room temperature until their usage in the experiments. Experiments were conducted in earthen pots of $25 \mathrm{~cm}$ diameter and $30 \mathrm{~cm}$ deep containing substrate $(50 \%$ sand and $50 \%$ compost). Forty seeds were planted in each pot at a depth of $2 \mathrm{~cm}$ at $20 \pm 3{ }^{\circ} \mathrm{C}$ mean temperature of sowing. After emergence, seedlings were thinned to 30 per pot and maintained until the desired growth stage. Experiments were laid out in Randomize Complete Block Design with factorial arrangement. There were four replications for each experiment.

\section{Treatments and chemicals}

Five herbicides, each at recommended rates without adjuvants and at reduced rates (up to recommended rates of $75 \%$ ) with adjuvants, were applied at the cotyledon- leaf and at the two-to- four leaf stages of plant growth (Table 1). Spray solutions were prepared by adding herbicides alone or herbicide and adjuvant in a plastic bottle containing tap water. Spray solutions were applied with hand held 
Table 1 - List of herbicides and adjuvants and their dose

\begin{tabular}{|c|c|c|}
\hline Herbicide & $\begin{array}{c}\text { Dose } \\
\left(\mathrm{g} \text { a.i. } \mathrm{ha}^{-1}\right)\end{array}$ & Adjuvants \\
\hline Weedy check & - & - \\
\hline Fluroxypyr+MCPA & $450.0^{*}$ & - \\
\hline Fluroxypyr+MCPA & 337.5 & Alkyl ether sulphate sodium salt @ $625 \mathrm{~mL} \mathrm{ha}^{-1}$ \\
\hline Fluroxypyr+MCPA & 337.5 & Fatty alcohol ethoxylate@ $375 \mathrm{~mL} \mathrm{ha}^{-1}$ \\
\hline Carfentrazone-ethyl & $20.0^{*}$ & - \\
\hline Carfentrazone-ethyl & 15.0 & Alkyl ether sulphate sodium salt @ $625 \mathrm{~mL} \mathrm{ha}^{-1}$ \\
\hline Carfentrazone-ethyl & 15.0 & Fatty alcohol ethoxylate@ $375 \mathrm{~mL} \mathrm{ha}^{-1}$ \\
\hline Bromoxynil+MC PA & $450.0^{*}$ & - \\
\hline Bromoxynil+MC PA & 337.5 & Alkyl ether sulphate sodium salt @ $625 \mathrm{~mL} \mathrm{ha}^{-1}$ \\
\hline Bromoxynil+MC PA & 337.5 & Fatty alcohol ethoxylate@ $375 \mathrm{~mL} \mathrm{ha}^{-1}$ \\
\hline Thifensulfuron-methyl & $75.0^{*}$ & - \\
\hline Thifensulfuron-methyl & 56.3 & Alkyl ether sulphate sodium salt @ $625 \mathrm{~mL} \mathrm{ha}^{-1}$ \\
\hline Thifensulfuron-methyl & 56.3 & Fatty alcohol ethoxylate $@ 375 \mathrm{~mL} \mathrm{ha}^{-1}$ \\
\hline Tribenuron-methyl & $75.0^{*}$ & - \\
\hline Tribenuron-methyl & 56.3 & Alkyl ether sulphate sodium salt @ $625 \mathrm{~mL} \mathrm{ha}^{-1}$ \\
\hline Tribenuron-methyl & 56.3 & Fatty alcohol ethoxylate@375 $\mathrm{mL} \mathrm{ha}^{-1}$ \\
\hline
\end{tabular}

* Recommended rate. Fluroxypyr+MCPA (Strane-M $60 \mathrm{EC}$ at $750 \mathrm{~mL} \mathrm{ha}^{-1}$ ) and Bromoxynil $+\mathrm{MCPA}\left(\right.$ Buctril super $60 \mathrm{EC}$ at $750 \mathrm{~mL} \mathrm{ha}^{-1}$ ) were a formulated mixture.

Knapsack sprayer. Pots were watered before spray application and no water was applied for the next 24 hours after application. Thereafter, water was applied regularly to maintain adequate moisture for the plant. Evaluation of E. spinosa control was made 21 days after treatment (DAT) and fresh weight, dry weight, root length and shoot length were measured. Control rating $(0-100 \%)$ was $0=$ no damage $/$ normal plant and $100=$ complete death of the plant foliage as approved by the Weed Science Society of America (Frans et al., 1986). Root and shoot length of completely killed plants were considered as zero. All the data were subjected to analysis of variance with the use, SAS (2002). Fisher's Protected LSD at the 5\% significance level of probability was used to separate the mean (Steel et al., 1997). Preplanned contrasts were used to compare herbicides at recommended rates without adjuvants, herbicides at reduced rates with the adjuvants and two adjuvants types.

\section{RESULTS AND DISCUSSION}

\section{Emex spinosa control of cotyledon-leaf stage}

Adjuvants such as alkyl ether sulphate sodium salt and fatty alcohol ethoxylate increased efficacy of fluroxypyr+MCPA, carfentrazone-ethyl and bromoxynil+MCPA at reduced rates, which gave similar control to the recommended rates of these herbicides without adjuvants (Figure 1). However, fluroxypyr+MCPA and carfentrazone-ethyl each at a recommended rate without the adjuvants or reduced rates with the adjuvants resulted in maximum mortality (100\%) of E. spinosa compared with $60 \%$ in bromoxynil+MCPA at the cotyledon- leaf stage (Figure 1). Bromoxynil+MCPA at a reduced rate with fatty alcohol ethoxylate caused more reduction in root/shoot fresh weight compared with its other treatments (Figure 1). Phytotoxicity of thifensulfuron-methyl at reduced rates decreased with both the adjuvants which resulted in lower weed control and reduction in root/shoot fresh and dry weight compared with its recommended rates without adjuvants. Whereas, phytotoxicity of tribenuron-methyl increased with the addition of adjuvants and resulted in more effective control and biomass reduction compared to its alone use (Figure 1). Complete plant mortality of E. spinosa with fluroxypyr+MCPA and carfentrazone-ethyl each at recommended rate without adjuvants or at reduced rates with both the adjuvants resulted in zero root and shoot length (Table 2 and 3). Bromoxynil+MCPA at a 


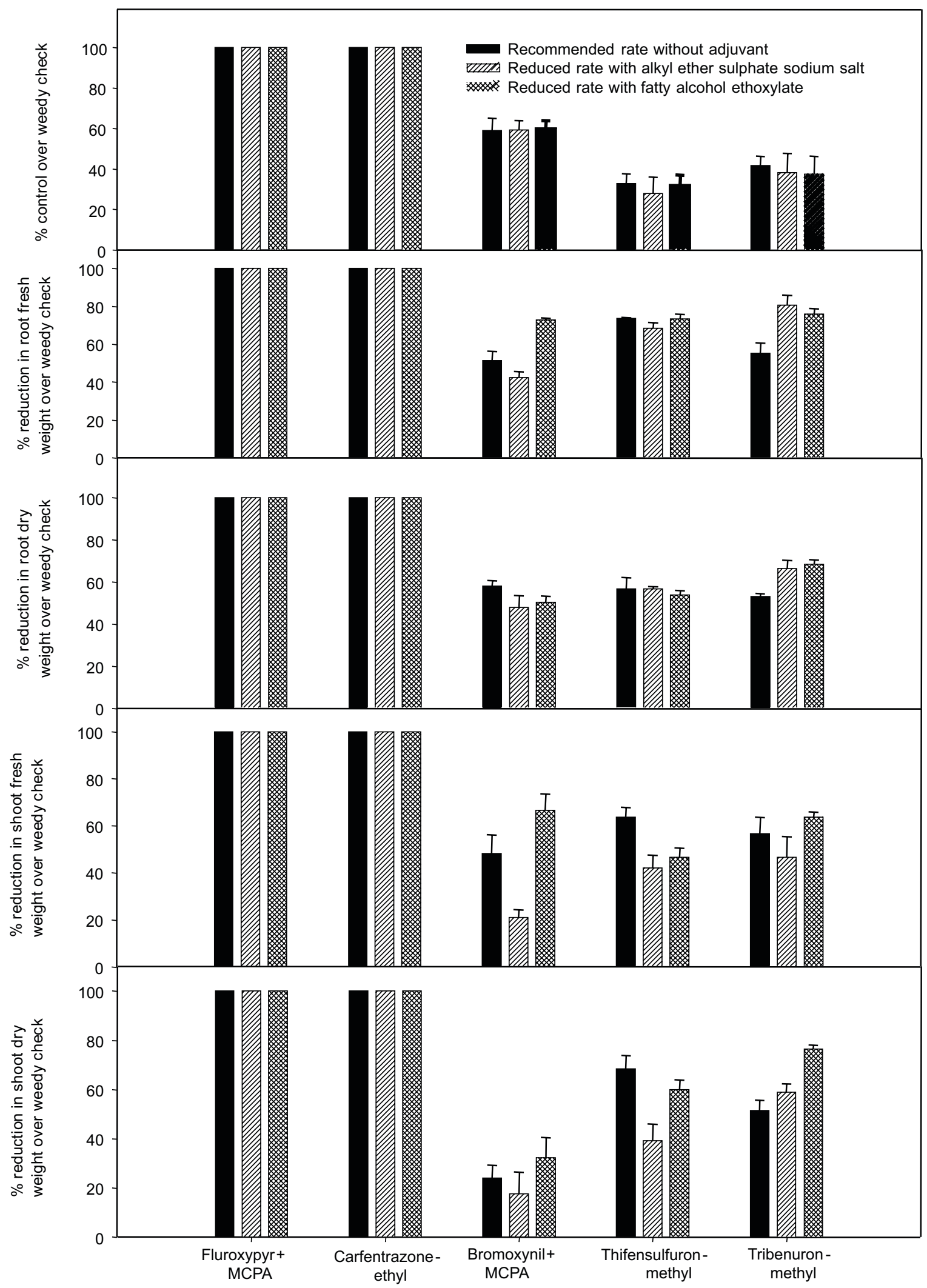

Figure 1 - Effect of herbicides at recommended rates without adjuvants and at reduced rates with adjuvants on percent control and percent reduction in root/shoot fresh and dry weight over weedy check of E. spinosa at cotyledon- leaf stage. 
reduced rate with fatty alcohol ethoxylate recorded lower root and soot length when compared with it alone use at a recommended rate or at reduced rates with alkyl ether sulphate sodium salt (Table 2 and 3 ). Whereas, the addition of adjuvants to bromoxynil+MCPA did not suppress the shoot growth of $E$. spinosa and measured the same shoot length to its alone use at recommended rates (Table 3). The addition of alkyl ether sulphate sodium salt to thifensulfuron-methyl at reduced rates did not improve its phytotoxicity and provided more root and shoot length than in other treatments. Whereas, addition of both the adjuvants to tribenuron-methyl at reduced rates increased its phytotoxicity and resulted in less root and shoot length than when used alone at recommended rates. Bromoxynil $+\mathrm{MCPA}$ at recommended rates without adjuvants or at reduced rates with both the adjuvants resulted in the same root/shoot ratio. Whereas, thifensulfuron-methyl at reduced rates with fatty alcohol exthoxylate showed minimum root/shoot ratio $(0,63)$ when compared with other treatments (Table 4).

Contrast comparisons showed that there was no significant difference in herbicides at recommended rates without adjuvants versus herbicides at reduced rates with alkyl ether sulphate sodium salt for control and percent reduction in root/shoot fresh and dry weight of E. spinosa (Table 5 contrast 1). Percent reduction in root fresh weight and shoot dry weight was higher with herbicides at reduced rate and with fatty alcohol ethoxylate when

Table 2 - Effect of herbicides at recommended rates without adjuvants and at reduced rates with adjuvants on root length (cm) of $E$. spinosa at the cotyledon- leaf stage

\begin{tabular}{|l|c|c|c|c|}
\hline \multirow{2}{*}{ Herbicide } & \multicolumn{3}{|c|}{ Dose/adjuvant combination } \\
\cline { 2 - 5 } & Recommended & $\begin{array}{c}\text { Reduced }+ \\
\text { Adjuvant A }\end{array}$ & $\begin{array}{c}\text { Reduced }+ \\
\text { Adjuvant B }\end{array}$ & Mean \\
\hline Fluroxypyr+MCPA & $0,00 \mathrm{e}$ & $0,00 \mathrm{e}$ & $0,00 \mathrm{e}$ & $0,00 \mathrm{C}$ \\
\hline Carfentrazone -ethyl & $0,00 \mathrm{e}$ & $0,00 \mathrm{e}$ & $0,00 \mathrm{e}$ & $0,00 \mathrm{C}$ \\
\hline Bromoxynil+MCPA & $3,40 \mathrm{~b}$ & $3,43 \mathrm{~b}$ & $2,63 \mathrm{~cd}$ & $3,15 \mathrm{~A}$ \\
\hline Thifensulfuron -methyl & $2,75 \mathrm{c}$ & $4,28 \mathrm{a}$ & $2,65 \mathrm{~cd}$ & $3,23 \mathrm{~A}$ \\
\hline Tribenuron -methyl & $3,48 \mathrm{~b}$ & $2,20 \mathrm{~d}$ & $2,38 \mathrm{~cd}$ & $2,68 \mathrm{~B}$ \\
\hline Mean & $1,93 \mathrm{~A}$ & $1,98 \mathrm{~A}$ & $1,53 \mathrm{~B}$ & \\
\hline \multicolumn{2}{|c|}{$\mathrm{LSD}_{0,05}$ for Herbicide $=0,29$, dose/adjuvant combination $=0,23$ and interaction $=0,51$} \\
\hline
\end{tabular}

Means not sharing the same letters differ significantly at $p \leq 0,05$ level. Adjuvant $\mathrm{A}=$ alkyl ether sulphate sodium salt and Adjuvant $\mathrm{B}=$ fatty alcohol ethoxylate.

Table 3 - Effect of herbicides at recommended rates without adjuvants and at reduced rates with adjuvants on shoot length (cm) of $E$. spinosa at the cotyledon- leaf stage

\begin{tabular}{|l|c|c|c|c|}
\hline \multirow{2}{*}{ Herbicide } & \multicolumn{3}{c|}{ Dose/adjuvant combination } \\
\cline { 2 - 5 } & Recommended & $\begin{array}{c}\text { Reduced }+ \\
\text { Adjuvant A }\end{array}$ & $\begin{array}{c}\text { Reduced }+ \\
\text { Adjuvant B }\end{array}$ & Mean \\
\hline Fluroxypyr+MCPA & $0,00 \mathrm{f}$ & $0,00 \mathrm{f}$ & $0,00 \mathrm{f}$ & $0,00 \mathrm{C}$ \\
\hline Carfentrazone -ethyl & $0,00 \mathrm{f}$ & $0,00 \mathrm{f}$ & $0,00 \mathrm{f}$ & $0,00 \mathrm{C}$ \\
\hline Bromoxynil+MCPA & $4,63 \mathrm{~b}$ & $4,50 \mathrm{bc}$ & $4,35 \mathrm{bc}$ & $4,49 \mathrm{~A}$ \\
\hline Thifensulfuron -methyl & $3,95 \mathrm{~cd}$ & $5,38 \mathrm{~A}$ & $4,18 \mathrm{bcd}$ & $4,50 \mathrm{~A}$ \\
\hline Tribenuron -methyl & $3,63 \mathrm{~d}$ & $2,80 \mathrm{e}$ & $2,55 \mathrm{e}$ & $2,99 \mathrm{~B}$ \\
\hline Mean & $2,44 \mathrm{AB}$ & $2,54 \mathrm{~A}$ & $2,22 \mathrm{~B}$ & \\
\hline \multicolumn{2}{|c|}{$\mathrm{LSD}_{0,05}$ for Herbicide $=0,38$, dose/adjuvant combination $=0,30$ and interaction $=0,66$} \\
\hline
\end{tabular}

Means not sharing the same letters differ significantly at $p \leq 0,05$ level. Adjuvant $\mathrm{A}=$ alkyl ether sulphate sodium salt and $\mathrm{Adjuvant} \mathrm{B}=$ fatty alcohol ethoxylate. 
Table 4 - Effect of herbicides at recommended rates without adjuvants and at reduced rates with adjuvants on root/shoot ratio of $E$. spinosa at the cotyledon- leaf stage

\begin{tabular}{|l|c|c|c|c|}
\hline \multirow{2}{*}{ Herbicide } & \multicolumn{3}{|c|}{ Dose/adjuvant combination } \\
\cline { 2 - 5 } & Recommended & $\begin{array}{c}\text { Reduced }+ \\
\text { Adjuvant A }\end{array}$ & $\begin{array}{c}\text { Reduced }+ \\
\text { Adjuvant B }\end{array}$ & Mean \\
\hline Fluroxypyr+MCPA & $0,00 \mathrm{e}$ & $0,00 \mathrm{e}$ & $0,00 \mathrm{e}$ & $0,00 \mathrm{C}$ \\
\hline Carfentrazone-ethyl & $0,00 \mathrm{e}$ & $0,00 \mathrm{e}$ & $0,00 \mathrm{e}$ & $0,00 \mathrm{C}$ \\
\hline Bromoxynil+MCPA & $0,74 \mathrm{~cd}$ & $0,77 \mathrm{~cd}$ & $0,65 \mathrm{~cd}$ & $0,72 \mathrm{AB}$ \\
\hline Thifensulfuron-methyl & $0,71 \mathrm{~cd}$ & $0,80 \mathrm{bc}$ & $0,63 \mathrm{~d}$ & $0,72 \mathrm{~B}$ \\
\hline Tribenuron-methyl & $0,96 \mathrm{a}$ & $0,89 \mathrm{bcd}$ & $0,94 \mathrm{ab}$ & $0,89 \mathrm{~A}$ \\
\hline Mean & 0,48 & 0,47 & 0,44 & \\
\hline \multicolumn{2}{|c|}{$\mathrm{LSD}_{0,05}$ for Herbicide $=0,09$, dose/adjuvant combination $=\mathrm{ns}$ and interaction $=0,15$} \\
\hline
\end{tabular}

Means not sharing the same letters differ significantly at $p \leq 0,05$ level. Adjuvant $\mathrm{A}=$ alkyl ether sulphate sodium salt and Adjuvant $\mathrm{B}=$ fatty alcohol ethoxylate.

Table 5 - Contrast comparison of herbicides and adjuvants on percent control, percent reduction in root/shoot fresh and dry weight over weedy check of E. spinosa at the cotyledon- leaf stage

\begin{tabular}{|c|c|c|c|c|c|c|}
\hline & \multirow{3}{*}{ Contrast } & \multirow{3}{*}{$\begin{array}{l}\text { Percent } \\
\text { control }\end{array}$} & \multicolumn{4}{|c|}{ Percent reduction over weedy check } \\
\hline & & & \multicolumn{2}{|c|}{ Root } & \multicolumn{2}{|c|}{ Shoot } \\
\hline & & & Fresh weight & Dry weight & Fresh weight & Dry weight \\
\hline 1 & Alone vs $\mathrm{H}+$ Adjuvant $\mathrm{A}$ & 67 vs $65^{\mathrm{ns}}$ & 76 vs $78^{\text {ns }}$ & 74 vs $74^{\text {ns }}$ & 78 vs $69^{\text {ns }}$ & 69 vs $63^{\text {ns }}$ \\
\hline 2 & Alone vs $\mathrm{H}+$ Adjuvant $\mathrm{B}$ & 67 vs $67^{\mathrm{ns}}$ & 76 vs $84^{*}$ & 74 vs $75^{\text {ns }}$ & 78 vs $80^{\text {ns }}$ & 69 vs $74^{*}$ \\
\hline 3 & Adjuvant A vs Adjuvant B & 65 vs $67^{\mathrm{ns}}$ & 78 vs $84^{*}$ & 74 vs $75^{\text {ns }}$ & 69 vs $80^{\text {ns }}$ & 63 vs $74^{*}$ \\
\hline
\end{tabular}

Alone $=$ Herbicides at recommended rates without adjuvants, $\mathrm{H}=$ Herbicides at reduced rates, Adjuvant $\mathrm{A}=$ alkyl ether sulphate sodium salt and Adjuvant $\mathrm{B}=$ fatty alcohol ethoxylate. ${ }^{\text {ns }}$ and * indicate non-significant and significant at $\mathrm{p} \leq 0,05$ level, respectively.

compared with herbicides at recommended rates without adjuvants (Table 5 contrast 2). Similarly, contrast of alkyl ether sulphate sodium salt versus fatty alcohol ehtoxylate was significant for percent reduction in root fresh weight and shoot dry weight (Table 5 contrast 3).

At the cotyledon- leaf stage, phytotoxicity of fluroxypyr+MCPA and carfentrazone-ethyl herbicides at their reduced rates with both the adjuvants was similar to the herbicides used at recommended rates without the adjuvants. These results are consistent with those of Bradford et al. (2002) who reported that adjuvants increase the phototoxicity of imazamethabenz when sprayed on the wild oat (Avena fatua) after emergence but prior to the two- leaf stage. The addition of adjuvants to thifensulfuron-methyl reduced its efficacy if compared with herbicide at recommended rates without adjuvants. Our findings are in contrast with those from James \& Rahman
(1992) who depicted that adjuvants improved thifensulfuron-methyl phytotoxicity to white mustard (Sinapis alab). From the results it can be concluded that fluroxypyr+MCPA and carfentrazone-ethyl each at a reduced rate with alkyl ether sulphate sodium salt or fatty alcohol ethoxylate is a best option for E. spinosa control at the cotyledon- leaf stage. Herbicides and adjuvants tank mixing, showed varied response for E. spinosa control and below ground and above ground biomass production so, the susceptibility of $E$. spinosa was related to herbicides as well as adjuvants dependent.

\section{Emex spinosa control of two- to four- leaf stage}

Fluroxypyr+MCPA at recommended rates without the adjuvants and at reduced rates with the adjuvants resulted in $100 \%$ mortality of E. spinosa at two- to four- leaf stage (Figure 2). The addition of both the adjuvants 


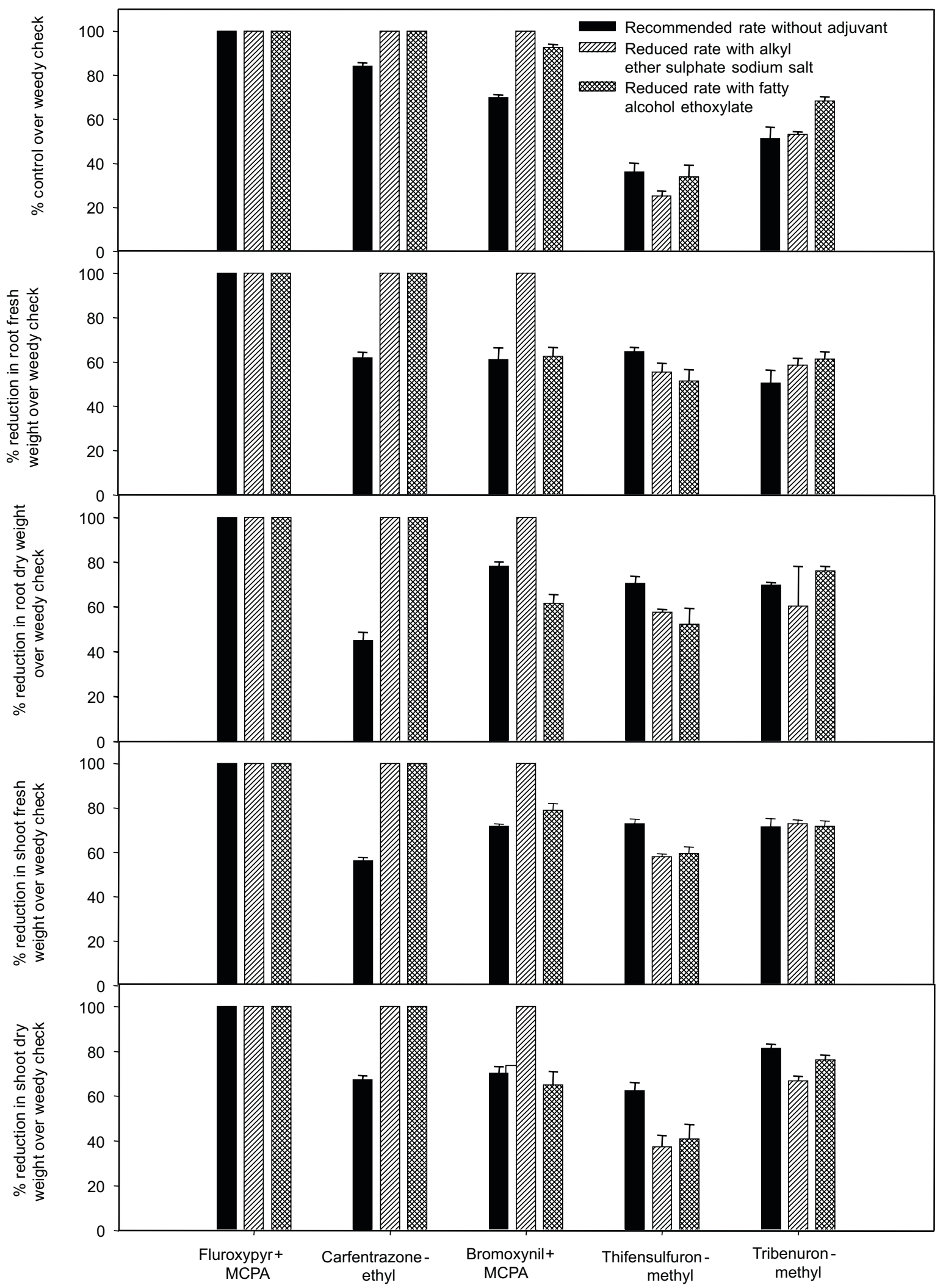

Figure 2 - Effect of herbicides at recommended rates without adjuvants and at reduced rates with adjuvants on percent control and percent reduction in root/shoot fresh and dry weight over weedy check of E. spinosa at the two- to four- leaf stage. 
to carfentrazone-ethyl at reduced rates increased its phytotoxicity in comparison with its alone use at recommended rates and resulted in 100\% mortality. Phytotoxicity of bromoxynil + MCPA at reduced rates also increased with the addition of both adjuvants however, bromoxynil+MCPA at reduced rates only with alkyl ether sulphate sodium salt resulted in $100 \%$ mortality of $E$. spinosa. Fatty alcohol ethoxylate slightly increased the phytotoxicity of tribenuron-methyl at reduced rates if compared with its alone use or at reduced rates with alkyl ether sulphate sodium salt and showed $68 \%$ control of E. spinosa (Figure 2). Both adjuvants decreased phytotoxicity of thifensulfuronmethyl at reduced rates and resulted in least control and biomass reduction of $E$. spinosa (Figure 2). Maximum (100\%) root/shoot fresh and dry weight reduction over weedy check was observed with fluroxypyr+MCPA at recommended rates without adjuvants and reduced rates of this herbicide with the adjuvants; carfentrazone-ethyl with both the adjuvants and bromoxynil+MCPA with alkyl ether sulphate sodium salt. Complete mortality of $E$. spinosa with fluroxypyr+MCPA at recommended rates without adjuvants or at reduced rates with both the adjuvants, carfentrazone-ethyl at reduced rates with both the adjuvants and bormoxynil+MCPA with alkyl ether sulphate sodium salt resulted in zero root and shoot length (Table 6 and 7). However, bromoxynil+MCPA at reduced rates with fatty alcohol ethoxylate measured lower root and shoot length when compared with its recommended rate without adjuvants. The addition of both the adjuvants to thifensulfuronmethyl at reduced rates did not suppress the root and shoot growth when compared with its recommended rate without adjuvants and resulted in similar and highest root and shoot length. Whereas, tribenuron-methyl at reduced rates with both the adjuvants suppressed root and shoot growth when compared to recommended rates without adjuvants (Table 6 and 7). In all herbicides treatments, maximum root/soot ratio was recorded with tribenuron-methyl. Root/shoot ratio was maximum with herbicides at recommended rates without adjuvants and minimum at reduced rates with alkyl ether sulphate sodium salt (Table 8).

In contrast, comparisons of herbicides at recommended rates without adjuvants versus herbicides at reduced rates with alkyl ether sulphate sodium salt were significant for control and percent reduction in root fresh and dry weight and shoot fresh weight over weedy check (Table 9 contrast 1). Similarly, contrast of herbicides at recommended rates without adjuvants versus herbicides at reduced rates with fatty alcohol ethoxylate was significant for control and percent reduction in root and shoot fresh weight (Table 9 contrast 2). Contrast of two adjuvant types was significant for root and shoot fresh weight.

Results indicated that the addition of adjuvants to carfentrazone-ethyl and bromoxynil+MCPA, each at reduced rates, improved their activity against E. spinosa and

Table 6 - Effect of herbicides at recommended rates without adjuvants and at reduced rates with adjuvants on root length (cm) of E. spinosa at the two- to four- leaf stag

\begin{tabular}{|l|c|c|c|c|}
\hline \multirow{2}{*}{ Herbicide } & \multicolumn{3}{|c|}{ Dose/adjuvant combination } \\
\cline { 2 - 5 } & Recommended & $\begin{array}{c}\text { Reduced }+ \\
\text { Adjuvant A }\end{array}$ & $\begin{array}{c}\text { Reduced }+ \\
\text { Adjuvant B }\end{array}$ & Mean \\
\hline Fluroxypyr+MCPA & $0,00 \mathrm{f}$ & $0,00 \mathrm{f}$ & $0,00 \mathrm{f}$ & $0,00 \mathrm{D}$ \\
\hline Carfentrazone-ethyl & $4,96 \mathrm{a}$ & $0,00 \mathrm{f}$ & $0,00 \mathrm{f}$ & $1,65 \mathrm{C}$ \\
\hline Bromoxynil+MCPA & $4,13 \mathrm{~b}$ & $0,00 \mathrm{f}$ & $1,95 \mathrm{e}$ & $2,03 \mathrm{C}$ \\
\hline Thifensulfuron-methyl & $4,24 \mathrm{ab}$ & $4,03 \mathrm{bc}$ & $4,15 \mathrm{~b}$ & $4,14 \mathrm{~A}$ \\
\hline Tribenuron-methyl & $4,70 \mathrm{ab}$ & $3,30 \mathrm{~cd}$ & $2,63 \mathrm{de}$ & $3,54 \mathrm{~B}$ \\
\hline Mean & $3,60 \mathrm{~A}$ & $1,47 \mathrm{~B}$ & $1,75 \mathrm{~B}$ & \\
\hline \multicolumn{2}{|c|}{$\mathrm{LSD}_{0,05}$ for Herbicide $=0,44$, dose/adjuvant combination $=0,34$ and interaction $=0,76$} \\
\hline
\end{tabular}

Means not sharing the same letters differ significantly at $p \leq 0,05$ level. Adjuvant $\mathrm{A}=$ alkyl ether sulphate sodium salt and Adjuvant $\mathrm{B}=$ fatty alcohol ethoxylate. 
Table 7 - Effect of herbicides at recommended rates without adjuvants and at reduced rates with adjuvants on shoot length (cm) of $E$. spinosa at the two- to four- leaf stage

\begin{tabular}{|l|c|c|c|c|}
\hline \multirow{2}{*}{\multicolumn{2}{c|}{ Herbicide }} & \multicolumn{3}{|c|}{ Dose/adjuvant combination } \\
\cline { 2 - 5 } & Recommended & $\begin{array}{c}\text { Reduced }+ \\
\text { Adjuvant A }\end{array}$ & $\begin{array}{c}\text { Reduced }+ \\
\text { Adjuvant B }\end{array}$ & Mean \\
\hline Fluroxypyr+MCPA & $0,00 \mathrm{f}$ & $0,00 \mathrm{f}$ & $0,00 \mathrm{f}$ & $0,00 \mathrm{E}$ \\
\hline Carfentrazone-ethyl & $5,80 \mathrm{bc}$ & $0,00 \mathrm{f}$ & $0,00 \mathrm{f}$ & $1,93 \mathrm{D}$ \\
\hline Bromoxynil+MCPA & $5,10 \mathrm{c}$ & $0,00 \mathrm{f}$ & $2,50 \mathrm{e}$ & $2,53 \mathrm{C}$ \\
\hline Thifensulfuron-methyl & $7,23 \mathrm{a}$ & $6,94 \mathrm{a}$ & $7,06 \mathrm{a}$ & $7,07 \mathrm{~A}$ \\
\hline Tribenuron-methyl & $6,00 \mathrm{~b}$ & $4,15 \mathrm{~d}$ & $3,83 \mathrm{~d}$ & $4,66 \mathrm{~B}$ \\
\hline Mean & $4,83 \mathrm{~A}$ & $2,22 \mathrm{C}$ & $2,68 \mathrm{~B}$ & \\
\hline \multicolumn{2}{|c|}{$\mathrm{LSD}_{0,05}$ for Herbicide $=0,43$, dose/adjuvant combination $=0,34$ and interaction $=0,75$} \\
\hline
\end{tabular}

Means not sharing the same letters differ significantly at $p \leq 0,05$ level. Adjuvant $\mathrm{A}=$ alkyl ether sulphate sodium salt and Adjuvant $\mathrm{B}=$ fatty alcohol ethoxylate.

Table 8 - Effect of herbicides at recommended rates without adjuvants and at reduced rates with adjuvants on root/shoot ratio of $E$. spinosa at the two- to four- leaf stage

\begin{tabular}{|l|c|c|c|c|}
\hline \multirow{2}{*}{\multicolumn{2}{c|}{ Herbicide }} & \multicolumn{3}{c|}{ Dose/adjuvant combination } \\
\cline { 2 - 5 } & Recommended & $\begin{array}{c}\text { Reduced }+ \\
\text { Adjuvant A }\end{array}$ & $\begin{array}{c}\text { Reduced }+ \\
\text { Adjuvant B }\end{array}$ & Mean \\
\hline Fluroxypyr+MCPA & $0,00 \mathrm{c}$ & $0,00 \mathrm{c}$ & $0,00 \mathrm{c}$ & $0,00 \mathrm{D}$ \\
\hline Carfentrazone-ethyl & $0,85 \mathrm{a}$ & $0,00 \mathrm{c}$ & $0,00 \mathrm{c}$ & $0,28 \mathrm{C}$ \\
\hline Bromoxynil+MCPA & $0,81 \mathrm{a}$ & $0,00 \mathrm{c}$ & $0,80 \mathrm{a}$ & $0,54 \mathrm{~B}$ \\
\hline Thifensulfuron-methyl & $0,59 \mathrm{~b}$ & $0,59 \mathrm{~b}$ & $0,60 \mathrm{~b}$ & $0,59 \mathrm{~B}$ \\
\hline Tribenuron-methyl & $0,81 \mathrm{a}$ & $0,79 \mathrm{a}$ & $0,72 \mathrm{ab}$ & $0,77 \mathrm{~A}$ \\
\hline Mean & $0,61 \mathrm{~A}$ & $0,28 \mathrm{C}$ & $0,42 \mathrm{~B}$ & \\
\hline \multicolumn{2}{|c|}{$\mathrm{LSD}_{0,05}$ for Herbicide $=0,10$, dose/adjuvant combination $=0,08$ and interaction $=0,19$} \\
\hline
\end{tabular}

Means not sharing the same letters differ significantly at $p \leq 0,05$ level. Adjuvant $\mathrm{A}=$ alkyl Ether Sulphate Sodium Salt and Adjuvant $\mathrm{B}=$ fatty alcohol ethoxylate.

Table 9 - Contrast comparison of herbicides and adjuvants on percent control, percent reduction in root/shoot fresh and dry weight over weedy check of E. spinosa at the two- to four- leaf stage

\begin{tabular}{|c|c|c|c|c|c|c|}
\hline & \multirow{3}{*}{ Contrast } & \multirow{3}{*}{$\begin{array}{l}\text { Percent } \\
\text { control }\end{array}$} & \multicolumn{4}{|c|}{ Percent reduction over weedy check } \\
\hline & & & \multicolumn{2}{|c|}{ Root } & \multicolumn{2}{|c|}{ Shoot } \\
\hline & & & Fresh weight & Dry weight & Fresh weight & Dry weight \\
\hline 1 & Alone vs $\mathrm{H}+$ Adjuvant $\mathrm{A}$ & 68 vs $76^{*}$ & 68 vs $83^{*}$ & 73 vs $84^{*}$ & 74 vs $86^{*}$ & 76 vs $81^{\mathrm{ns}}$ \\
\hline 2 & Alone vs $\mathrm{H}+$ Adjuvant $\mathrm{B}$ & 68 vs $79^{*}$ & 68 vs $75^{*}$ & 73 vs $78^{\text {ns }}$ & 74 vs $81^{*}$ & 76 vs $76^{\mathrm{ns}}$ \\
\hline 3 & Adjuvant A vs Adjuvant B & 76 vs $79^{\mathrm{ns}}$ & 83 vs $75^{*}$ & 84 vs $78^{\text {ns }}$ & 86 vs $81^{*}$ & $81 \mathrm{vs} 76^{\mathrm{ns}}$ \\
\hline
\end{tabular}

Alone $=$ Herbicides at recommended rates without adjuvants, $\mathrm{H}=$ Herbicides at reduced rates, Adjuvant $\mathrm{A}=$ alkyl ether sulphate sodium salt and Adjuvant $\mathrm{B}=$ fatty alcohol ethoxylate. ${ }^{n s}$ and $*$ indicate non-significant and significant at $\mathrm{p} \leq 0,05$ level, respectively.

these herbicides at reduced rate with the adjuvants are the most effective option for controlling E. spinosa at the two- to four- leaf stage. Fluroxypyr+MCPA at recommended rates without adjuvants and at reduced rates with the adjuvants showed similar results on
E. spinosa controled efficiency, so the application of fluroxypyr+MCPA at reduced rates with the adjuvants is also a cost effective option for E. spinosa management. These results are supported by Woznica et al. (2007) who applied triflusulfuron without adjuvants 
at recommended rates and at reduced rates (60\% of the recommended) with adjuvant (methylated seed oil) on Chenapodium album, Galium aparin, Solanum nigrum, Violva arvensis and Cirsium arvensis. They found that adjuvants increased the efficacy of herbicide at reduced rates and control was almost similar to that of its recommended rate without adjuvant. In our findings, all thifensulfuronmethyl and tribenuron-methyl treatments showed less than $70 \%$ E. spinosa control efficiency, above ground and below ground biomass reduction over weedy check. These herbicides with or without adjuvants are not effective for controlling for $E$. spinosa at two- to four- leaf stage and are not included in E. spinosa management programme. Similarly, Kumar et al. (2006) reported that the addition of adjuvants to trifloxysulfuron did not improve the efficacy against Cyperus rotundus, Trianthema portulacastrum, Chloris inflate and Chloris barbata. In another study, Pearson et al. (2008) reported that urea ammonium nitrate addition to bispyribac and penosulam increased their activity but the control was weed growthstage dependent. They also reported that barnyard grass biomass reduction was $95 \%$ to 99\% with either herbicide at three- to fourleaf stage and was reduced up to $88 \%$ when applied at one- to three- tillers stage.

Overall, spray adjuvants have potential to improve the efficacy of herbicides except from thifensulfuron-methyl against $E$. spinosa at cotyledon- leaf stage or two- to four- leaf stage. In the herbicides comparison study, fluroxypyr+ MCPA and carfentrazone-ethy each of them at reduced rates with adjuvants were more effective for controllingon $E$. spinosa at both the leaf stages. Improved efficacy is likely attributed to increased foliar penetration of these herbicides and the herbicides have the same or more phytotoxicity against $E$. spinosa at the cotyledon- leaf stage or two- to fourleaf stage with the addition of adjuvants. Carfentrazone-ethyl without adjuvant when sprayed at the cotyledon- leaf stage provided more effective control and root/shoot biomass reduction as compared to when sprayed at the two- to four- leaf stage. Reduced efficacy at the two- to four- leaf stage may be due to the development of waxy cutical layer in leaves which increased the surface tension that caused hinderence in herbicide retention, penetration and translocation. These results are in line with those of Klingman et al. (1992) who reported that imazethapyr provided significanlty higher control of Sorghum halepense and Echinochloa crus-galli at the cotyledon or at the one-true leaf stage as compared to three-true leaf stage. Addition of alkyl ether sulphate sodium salt also increased the phytotoxicity of bromoxynil+ MCPA at reduced rates when sprayed at two- to four- leaf stage. A previous study reported that adjuvants improve the efficacy by absorption and spray retention of hebicides with the additio of adjuvants (Adamczewski \& Matysiak 2005; Kocher \& Kocur 2006; Bernards et al., 2009). There was no difference between two adjuvant types for $E$. spinosa control at the cotyledon-leaf stage or two- to four- leaf stag so alkyl ether sulphate sodium salt or fatty alcohol ethoxylate may be included in E. spinosa management program.

\section{ACKNOWLEDGMENTS}

We gratefully acknowledge the Higher Education Commission of Pakistan for providing financial support under the Indigenous Ph.D. fellowship program.

\section{LITERATURE CITED}

ADAMCZEWSKI, K.; MATYSIAK, R. The effects and benefits of adjuvants used with sulfonylourea herbicides. Progress Plant Protec., v. 45, n. 1, p. 17-24, 2005.

BERNARDS, M. L. et al. Imazapyr absorption and translocation in northern red oak and red maple as affected by herbicide formulation and the adjuvant methylated seed oil. J. ASTM Int., v. 6, n. 6, p. 102163-102163, 2009

BRADFORD, K. et al. Low-rate split-applied herbicide treatments for wild oat (Avena fatua) control in wheat (Triticum aestivum). Weed Technol., v. 16, n. 1, p. 149-155, 2002.

BUNTING, J. A. et al. Absorption and activity of foramsulfuron in giant foxtail (Setaria faberi) and woolly cupgrass (Eriochloa villosa) with various adjuvants. Weed Sci., v. 52, n. 4, p. 513-517, 2004.

BURDON, J.; MARSHALL, D. Biological control and the reproductive mode of weeds. J. Appl. Ecol., v. 18, n. 2, p. 649-658, 1981.

FRANS, R. et al. Experimental design and techniques for measuring and analyzing plant response to weed control practices. In: CAMPER, N.D., ed. Research methods in weed science. Champaign: Southern Weed Science Society, 1986. p. $29-46$ 
GREEN, J. M.; CAHILL, W. R. Enhancing the biological activity of nicosulfuron with $\mathrm{pH}$ adjusters. Weed Sci., v. 17, n. 2 , p. $338-345,2003$.

HAZEN, J. L. Adjuvants-Terminology, classification and chemistry 1. Weed Technol., v. 14, n. 4, p. 773-784, 2000.

HOSAKA, E.Y.; THISTLE, A. Noxious plants of the hawaiian ranges. University of Hawaii, 1954. 6239 p. (Extention Bulletin)

JAMES, T. K.; RAHMAN, A. Effect of simulated rainfall and adjuvants on the phytotoxicity of sulfonylurea herbicides. In: INTERNATIONAL WEED CONTROL CONGRESS 1, 1992. Australia, Proceedings... Australia1992. v. 2, p. 229-232,

KAMMOUN, L. G.; SOUISSI, T. First report of Cercospora tripolitana causing leaf spot on Emex spinosa in Tunisia. Plant Dis., v. 93, n. 7, p. 763, 2009.

KLINGMAN, T. E. et al. Effect of application rates, weed species, and weed stage of growth on imazethapyr activity. Weed Sci., v. 40, n. 2, p. 227-232, 1992.

KOCHER, H.; KOCUR, J. Influence of wetting agents on the foliar uptake and herbicidal activity of glufosinate. Pestic. Sci., v. 37, n. 1, p. 155-158, 2006.

KUMAR, G. P. et al. Effect of early post-emergence herbicides for control of weeds in winter irrigated upland cotton (Gossypium hirsutum). Indian J. Agron., v. 51, n. 4, p. 323-326, 2006.

LU, M. et al. A study on synergistic effects of methyl oleate adjuvant on herbicides and their safety on maize seedlings. Plant Protec., v. 31, n. 1, p. 83-85, 2005.

MOTOOKA, P. et al. Weeds of hawaii's pastures and natural areas. Honolulu: University Hawaii College of Tropical Agriculture and Human Resources, 2003. 184 p.
PEARSON, B. A et al. Urea ammonium nitrate effects on bispyribac and penoxsulam efficacy. Weed Technol., v. 22, n. 4, p. 597-601, 2008.

SAS. Statistical Analysis Systems. SAS Procedures Guide. Version 9. Cary: Statistical Analysis Systems Institute, 2002.

STEEL, R. G. D. et al. Principles and procedures of statistics. Multiple comparisons. 3.ed. New York: McGraw Hill Book, 1997. p. 178-198.

STEINHEIL, A. D. Flore de barbarie in annales des sciences naturelles, Tome douzieme-botanique. $2^{\text {nd }}$ Series. Paris: Crochard and Co, Libraires-edituri, Place de lecole-de-medecine, 1838. p. 193

WANAMARTA, G.; PENNER, D. Foliar penetration of herbicides. Weed Sci., v. 4, n. 1, p. 215-231, 1989.

WILSON, F. The biological control of weeds. An. Rev. Entomol., v. 9, n. 1, p. 225-244, 1964.

WOZNICA, Z. Effect of adjuvants on the phytotoxicity of the herbicide flumiclorac-pentyl. Prace Zakresu Nauk Rolniczych, v. 79, n.1, p. 163-168, 1995.

WOZNICA, Z. et al. Effect of adjuvants on possibility of herbicide rate reduction for weed control in sugarbeet.

Fragmenta Agron., v. 24, n. 4, p. 261-266, 2007.

ZABKIEWICZ, J. A. Adjuvants and herbicidal efficacy: present status and future prospects. Weed Res., v. 40, n. 1, p. 139-149, 2000.

ZAWIERUCHA, J. E.; PENNER, D. Adjuvant Efficacy with Quinclorac in Canola (Brassica napus) and Turfgrass. Weed Technol., v. 15, n. 2, p. 220-223, 2001a.

ZAWIERUCHA, J. E.; PENNER, D. The relationship of goosegrass (Eleusine indica) stage of growth to quinclorac tolerance. Weed Technol., v. 15, n. 2, p. 216-219, 2001 b. 